\title{
PENGARUH JENIS RAGI PADA FERMENTASI KAKAO TERHADAP KARAKTERISTIK CUKA KAKAO
}

The Effect of "Ragi" on Cocoa Fermentation to The Characteristics of Cocoa Vinegar

\author{
Nur Wienda Permata Wulandari' ${ }^{1)}$, Dewa Gde Mayun Permana ${ }^{2)}$, Agus Selamet Duniaji ${ }^{2)}$ \\ ${ }^{1}$ Mahasiswa Program Studi Ilmu dan Teknologi Pangan, Fakultas Teknologi Pertanian, Universitas Udayana \\ ${ }^{2}$ Dosen Program Studi Ilmu dan Teknologi Pangan, Fakultas Teknologi Pertanian, Universitas Udayana \\ Kampus Bukit Jimbaran, Badung-Bali
}

\begin{abstract}
This research was aimed to determine the effect type of "ragi" on the fermentation process of cocoa and to determine type of "ragi" that can produce vinegar with the best characteristics. This research used Randomized Block Design (RBD) with four types treatment of "ragi", these are: without the addition of "ragi", addition of bread yeast, addition of "tape ragi", and addition of combination "ragi". "Ragi" additions were carried out as much as $1 \%$ in each treatment. This research was repeated three times, resulting in 12 experimental units. The data was analyzed with Anova test and continued with Duncan test if the treatment had a significant effect $(P<0.05)$ on the observed variable. This research showed that the treatment fermentation addition of tape ragi was the best treatment with characteristic $5.05 \mathrm{pH}, 0.88 \%$ total acid, $3.33 \%$ total soluble solids, $0.59 \%$ total sugar and $0 \%$ alcohol.
\end{abstract}

Keyword: cocoa, ragi, vinegar, fermentation

\section{PENDAHULUAN}

Tanaman kakao (Theobroma cacao) merupakan tanaman hasil perkebunan yang banyak tumbuh di daerah beriklim tropis. Indonesia merupakan salah satu negara terbesar ketiga penghasil kakao di dunia setelah Pantai Gading (Ivory Coast) dan Ghana, produksi kakao di Indonesia sebesar 657.100 ton (Anon, 2017). Namun biji kakao di Indonesia saat ini masih memiliki mutu biji kakao yang rendah, sehingga menurunkan nilai jual dari biji kakao. Hal ini dikarenakan proses fermentasi biji kakao masih belum dilakukan dengan merata pada setiap daerah. Pemerintah saat ini sedang gencarnya mendorong pengolahan kakao secara fermentasi.

Salah satu hasil samping dari fermentasi biji kakao adalah cairan pulpa. Selama ini cairan pulpa hasil fermentasi biji kakao dibuang begitu saja yang menyebabkan kerusakan pada lingkungan karena cairan pulpa mempunyai nilai Chemical Oxygen Demand (COD) dan Biologycal Oxygen Demand (BOD) yang tinggi (Chin, 2006).

\footnotetext{
*Korespondesi Penulis :

E-mail: permatawienda47@gmail.com ${ }^{1)}$
}

Cairan pulpa yang dihasilkan selama fermentasi biji kakao sebanyak 15-20\% dari berat biji kakao yang difermentasi (Putra et al., 2008). Cairan pulpa hasil fermentasi kakao merupakan komponen limbah buah kakao yang belum dimanfaatkan secara maksimal, padahal limbah cairan pulpa hasil fermentasi biji kakao mempunyai nilai ekonomi yang tinggi. Cairan pulpa hasil fermentasi biji kakao memiliki kandungan asam asetat sebesar 1,6 \% (Case, 2004). Cairan pulpa yang memiliki kandungan asam asetat ini dapat digunakan sebagai bahan dasar dalam pembuatan vinegar atau cuka makan.

Perbedaan jenis ragi yang ditambahkan untuk mempercepat fermentasi biji kakao akan mempengaruhi mikroba yang berperan dalam proses fermentasi. Perbedaan mikroba yang berperan dalam proses fermentasi akan berpengaruh terhadap karakteristik cairan pulpa hasil fermentasi biji kakao. Apabila cairan tersebut digunakan sebagai bahan dasar pembuatan cuka maka akan memberikan karakteristik cuka yang berbeda. 
Tujuan dari penelitian ini adalah untuk mengetahui pengaruh jenis ragi pada proses fermentasi kakao terhadap karakteristik cuka kakao dan jenis ragi yang dapat menghasilkan karakteristik cuka kakao dengan karakteristik terbaik.

\section{METODE PENELITIAN}

\section{Tempat dan Waktu}

Fermentasi biji kakao dilaksanakan di Desa Angkah Kab. Tabanan, Bali. Proses analisis dilaksanakan di Laboratorium Analisis Pangan, Laboratorium Pengolahan Pangan Fakultas Teknologi Pertanian dan UPT. Laboratorium Analitik Universitas Udayana. Pelaksanaan penelitian dilakukan pada bulan Juni sampai dengan bulan September 2018.

\section{Bahan dan Alat}

Bahan yang digunakan dalam penelitian ini adalah buah kakao lindak yang diperoleh dari Desa Angkah, Kec. Selemadeg Barat, Kab. Tabanan, Bali. Bahan-bahan lain yang digunakan yaitu: ragi tape (Na Kok Liong), ragi roti (Fermipan), aquades, $\mathrm{NaOH} 0,1 \mathrm{~N}$, Phenolphthalein 1\%, HCL $4 \mathrm{~N}$ Arsenomolybdat, Nelson A, Nelson B, $\mathrm{H}_{2} \mathrm{SO}_{4}$ dan D-glukosa.

Alat yang digunakan dalam penelitian ini adalah pisau, wadah fermentasi (kayu), baskom, ayakan 40 mesh, timbangan digital, timbangan analitik, erlenmeyer, kain saring, kertas saring, daun pisang, tabung reaksi, alat pemanas, pipet tetes, pipet volum, buret, alumunium foil, tissue, termometer, kuvet, high performance liquid chromatography (HPLC) Shimatzu Varian, pH meter, handrefractometer, spektrofotometer UV-Vis (Genesys 10S UV-Vis), waterbath, labu takar (Pyrex), gelas ukur (Pyrex), gelas beaker (Pyrex), cromatography dan botol-botol kaca.

\section{Rancangan Percobaan}

Rancangan yang digunakan pada penelitian ini adalah Rancangan Acak
Kelompok (RAK) yang terdiri dari 4 perlakuan yaitu:

P1 : tanpa ragi/alami,

$\mathrm{P} 2$ : penambahan ragi roti $1 \%$,

$\mathrm{P} 3$ : penambahan ragi tape $1 \%$

$\mathrm{P} 4$ : penambahan ragi roti dan ragi tape/kombinasi 1\% (1:1).

Masing-masing perlakuan diulang 3 kali sehingga diperoleh 12 unit percobaan. Data yang diperoleh dianalisis dengan sidik ragam (ANOVA) dan dilanjutkan uji Duncan's Multiple Range Test (DMRT) apabila perlakuan berpengaruh signifikan $(\mathrm{P}<0,05)$ terhadap variabel yang diamati (Gomez dan Gomez, 1995).

\section{Pelaksanaan Penelitian}

Tahap pelaksanaan penelitian meliputi proses fermentasi biji kakao dan proses pengolahan cuka kakao.

1. Fermentasi Biji Kakao

Fermentasi biji kakao menggunakan wadah fermentasi berupa kotak kayu yang memiliki kapasitas tampung $40 \mathrm{~kg}$ biji kakao. Ragi roti dan ragi tape terlebih dahulu dihancurkan dengan cara ditumbuk kemudian diayak dengan ayakan 40 mesh, untuk perlakuan kombinasi ragi roti dan ragi tape dengan perbandingan 1:1 diaduk hingga homogen sebelum digunakan (Silfia et al., 2017).

Biji kakao sebanyak $40 \mathrm{~kg}$ dimasukkan ke dalam kotak fermentasi. Dilakukan penambahan ragi sebanyak $1 \%$ sesuai perlakuan pada masing-masing kotak fermentasi dan dilakukan pengadukan secara merata, kemudian biji kakao ditutup dengan daun pisang. Fermentasi dilakukan selama 3 hari, dengan pengadukan yang dilakukan setelah proses fermentasi berlangsung selama 2 hari (48 jam). Cairan pulpa yang diperoleh ditampung pada wadah plastik untuk dijadikan bahan pembuatan cuka. Proses fermentasi pulpa kakao dapat dilihat pada Gambar 1.

2. Pengolahan Cuka Kakao 
Proses pengolahan cuka kakao dilakukan dengan menggunakan metode fermentasi alami secara aerob dengan mengalirkan udara menggunakan aerator. Proses pengolahan diawali dengan pengambilan cairan pulpa hasil fermentasi kakao yang kemudian disaring dengan menggunakan kain saring untuk memisahkan kotoran yang terdapat pada cairan. Cairan yang telah disaring dimasukan ke dalam wadah botol kaca dengan volume jumlah cairan sebanyak $500 \mathrm{~mL}$ dan diatur volume head space tidak lebih dari $10 \%$ dari kapasiatas wadah fermentasi. Dialiri selang aerator pada botol, kemudian botol ditutup menggunakan kain untuk mencegah benda asing masuk ke dalam cairan fermentasi. Fermentasi dilakukan dengan penyimpanan pada suhu ruang selama 6 hari (Aridona et al, 2015). Dilakukan pengujian pada cuka yang dihasilkan.

\section{Variabel yang Diamati}

Variabel yang diamati dalam penelitian ini adalah $\mathrm{pH}$ (Apriyanto et al., 1989), total asam (James, 1995), total padatan terlarut (Muchtadi, 1989), total gula (Sudarmadji et al.,1984) dan alkohol (AOAC, 1990).

\section{HASIL DAN PEMBAHASAN}

Hasil analisis pada cuka kakao terhadap variabel uji derajat keasaman $(\mathrm{pH})$ dan total asam pada cuka kakao dapat dilihat pada tabel 1. Hasil analisis pada cuka kakao terhadap variabel uji total padatan terlarut (TPT), total gula dan alkohol dapat dilihat pada Tabel 2.

\section{Derajat Keasaman (pH)}

Berdasarkan hasil analisis ragam perbedaan jenis ragi pada fermentasi cuka berpengaruh sangat nyata $(\mathrm{P}<0,01)$ terhadap derajat keasaman $(\mathrm{pH})$ pada cuka. Pada Tabel 1 menunjukkan bahwa besar nilai $\mathrm{pH}$ pada cuka kakao berkisar antara 5,05-5,55. Nilai $\mathrm{pH}$ tertinggi pada perlakuan alami (P1) yang menunjukkan nilai berbeda tidak nyata dengan perlakuan penambahan ragi roti (P2), dan nilai $\mathrm{pH}$ terendah pada perlakuan penambahan ragi tape (P3) yang tidak berbeda dengan perlakuan kombinasi (P4).

Perlakuan penambahan ragi tape (P3) memiliki nilai $\mathrm{pH}$ terendah dikarenakan banyaknya kandungan asam asetat pada bahan. Banyaknya kandungan asam asetat pada bahan dikarenakan pada proses awal fermentasi ragi tape memiliki kandungan yeast yang merubah gula menjadi alkhol dan perubahan alkohol menjadi asam asetat dibantu dengan adanya kandungan bakteri asam asetat yang menyebabkan perubahan alkohol menjadi asam asetat lebih cepat dan banyak, dibandingkan dengan perlakuan kombinasi (P4) yang hanya memiliki setengah dari kandungan ragi tape pada perlakuan (P3). Pada perlakuan alami (P1) dan perlakuan penambahan ragi roti $(\mathrm{P} 2)$ perubahan alkohol menjadi asam asetat terjadi secara alami karena kontaminasi lingkungan sehingga menghasilkan nilai asam yang rendah dan mempengaruhi nilai $\mathrm{pH}$.

\section{Total Asam}

Berdasarkan hasil analisis ragam perbedaan jenis ragi pada fermentasi cuka berpengaruh sangat nyata $(\mathrm{p}<0,01)$ terhadap total asam pada cuka. Pada Tabel 1 menunjukkan bahwa besar nilai total asam pada cuka kakao berkisar antara 0,71\%$0,88 \%$. Nilai total asam tertinggi pada perlakuan penambahan ragi tape (P3) yang memiliki nilai berbeda tidak nyata pada perlakuan kombinasi (P4)dan nilai total asam terendah pada perlakuan alami (P1).

Perbedaan kadar asam pada setiap perlakuanproses fermentasi disebabkan oleh kandungan mikroba pada awal proses fermentasi. Pada perlakuan alami (P1) kandungan mikroba pada awal fermentasi sangat rendah akibatnya perombakan gula menjadi alkohol yang selanjutnya diubah menjadi asam asetat menjadi lebih lambat atau sedikit. 
Tabel 1. Nilai rata-rata derajat keasaman $(\mathrm{pH})$ dan total asam cuka kakao

\begin{tabular}{ccc}
\hline PerlakuanJenisRagi & $\mathrm{pH}$ & Total asam (\%) \\
\hline Alami & $5,55 \pm 0,07 \mathrm{a}$ & $0,71 \pm 0,06 \mathrm{c}$ \\
Ragi roti & $5,46 \pm 0,08 \mathrm{a}$ & $0,78 \pm 0,03 \mathrm{~b}$ \\
Ragi tape & $5,05 \pm 0,05 \mathrm{~b}$ & $0,88 \pm 0,06 \mathrm{a}$ \\
Kombinasi & $5,14 \pm 0,02 \mathrm{~b}$ & $0,83 \pm 0,08 \mathrm{ab}$ \\
\hline
\end{tabular}

Keterangan: Huruf yang sama di belakang nilai rata-rata pada kolom yang sama $\quad$ menunjukkan perlakuan berbeda tidak nyata $(\mathrm{P}>0,05)$.

Pada perlakuan penambahan ragi roti (P2) hasil tidak berbeda dengan perlakuan alami (P1) karena pada ragi roti hanya mengandung yeast yang berperan dalam perubahan gula menjadi alkohol saja, perubahan alkohol menjadi asam asetat terjadi secara alami karena kontaminasi dari lingkungan karena tidak adanya kandungan bakteri pada ragi roti. Perlakuan penambahan ragi tape (P3) memiliki kandungan total asam yang tidak berbeda dengan perlakuan kombinasi (P4). Hal ini dikarenakan kondisi ragi tape mengandung yeast dan bakteri asam asetat yang berperan pada proses perombakan gula menjadi alkohol dan dilanjutkan menjadi asam asetat, sehingga asam asetat dapat dihasilkan dengan cepat dan dalam jumlah yang banyak. Kondisi perlakuan kombinasi (P4) sama dengan perlakuan ragi tape (P3) karena merupakan pencampuran antara ragi roti dan ragi tape, tetapi karena hanya terdiri dari setengah kandungan ragi tape makanhasil asam asetat yang dihasilkan lebih sedikitdibandingkan pada perlakuan ragi tape (P3).

\section{Total Padatan Terlarut (TPT)}

Berdasarkan hasil analisis ragam perbedaan jenis ragi pada fermentasi cuka berpengaruh nyata $(\mathrm{P}<0,05)$ terhadap total padatan terlarut pada cuka.Pada Tabel 2 menunjukkan bahwa besar nilai total padatan terlarut (TPT) pada cuka kakao berkisar antara 3,33\% - 4,66\%, nilai total padatan terlarut tertinggi pada perlakuan alami (P1) yang memiliki nilai tidak berbeda dengan perlakuan kombinasi (P4) dan perlakuan penambahan ragi roti $(\mathrm{P} 2)$, sedangkan nilai total padatan terlarut terendah pada perlakuan penambahan ragi tape (P3).

Selama proses fermentasi cuka senyawa-senyawa yang terkandung seperti gula, garam-garam dan senyawa-senyawa yang terlarut dalam bahan dimetabolisme oleh yeast menjadi alkohol dan $\mathrm{CO}_{2}$, serta dimanfaatkan oleh bakteri sebagai sumber karbon. Sisa-sisa senyawa organik seperti glukosa, sukrosa maupun laktosa yang terdapat pada substrat hasil fermentasi terhitung sebagai total padatan terlarut (Sintasari, 2014). Selama proses fermentasi berlangsung berkurangnya gula disebabkan oleh metabolisme yeast menjadi alkohol dan $\mathrm{CO}_{2}$. Pada perlakuan penambahan ragi tape (P3) memiliki nilai total padatan terlarut (TPT) yang terendah dikarenakan pada awal proses fermentasi kandungan yeast pada tape aktif berperan dalam proses perombakan

Tabel 2. Nilai rata-rata total padatan terlarut (TPT), total gula dan alkohol cuka kakao

\begin{tabular}{llll}
\hline PerlakuanJenisRagi & TPT $(\%)$ & Total gula $(\%)$ & Alkohol (\%) \\
\hline Alami & $4,66 \pm 0,58 \mathrm{a}$ & $0,67 \pm 0,04 \mathrm{a}$ & 0,00 \\
Ragi roti & $4,00 \pm 0,00 \mathrm{ab}$ & $0,62 \pm 0,09 \mathrm{ab}$ & 0,00 \\
Ragi tape & $3,33 \pm 0,58 \mathrm{~b}$ & $0,59 \pm 0,07 \mathrm{~b}$ & 0,00 \\
Kombinasi & $4,33 \pm 0,58 \mathrm{a}$ & $0,63 \pm 0,03 \mathrm{ab}$ & 0,00 \\
\hline
\end{tabular}

Keterangan: Huruf yang sama di belakang nilai rata-rata pada kolom yang sama menunjukkan perlakuan berbeda tidak nyata $(\mathrm{P}>0,05)$. 
gula menjadi alkohol yang kemudian dimanfaatkan oleh bakteri asam asetat sebagai sumber karbon untuk menghasilkan asam asetat, selain itu terdapatnya kandungan bakteri asam asetat pada ragi tape mempercepat proses perubahan alkohol menjadi asam asetat. Berbeda dengan perlakuan penambahan ragi roti $(\mathrm{P} 2)$ dan perlakuan kombinasi (P4) yang memiliki nilai lebih tinggi dikarenakan rendahnya kandungan yeast yang memetabolisme gula menjadi alkohol dan perubahan alkohol menjadi asam asetat dilakukan secara spontan oleh lingkungan, sedangkan pada perlakuan alami (P1) seluruh proses fermentasi terjadi karena adanya kontaminasi dari lingkungan, sehingga nilai total padatan terlarut yang terkandung tinggi. Menurut penelitian Sintasari (2014), tingginya bahan-bahan organik yang terlarut pada bahan menjadi salah satu penyebab tingginya padatan terlarut.

\section{Total Gula}

Berdasarkan hasil analisis ragam perbedaan jenis ragi pada fermentasi cuka berpengaruh nyata $(\mathrm{P}<0,05)$ terhadap total gula pada cuka. Pada Tabel 2 menunjukkan bahwa besar nilai total gula pada cuka kakao berkisar antara 0,59\%-0,67\%. Nilai total gula tertinggi pada perlakuan alami (P1) yang tidak berbeda dengan perlakuan penambahan ragi roti $(\mathrm{P} 2)$ dan perlakuan kombinasi $(\mathrm{P} 4)$, dan nilai total gula terendah pada perlakuan penambahan ragi tape (P3).

Pada perlakuan penambahan ragi tape (P3) memiliki nilai total gula yang rendah dikarenakan lebih banyak mengandung yeast sehingga pada proses fermentasi perombakan gula menjadi alkohol lebih optimal. Berdasarkan penelitian (Simbolon, 2008) menyatakan jumlah mikroba perombak yang terdapat di dalam ragi tape lebih banyak, terutama enzim zimase yang dihasilkan semakin banyak, sehingga semakin banyak glukosa yang dirombak menjadi alkohol dan akibatnya kandungan gula menurun. Jika dibadingkan dengan perlakuan penambahan ragi roti (P2) yang hanya memiliki kandungan Saccharomyces cerevisiae dan perlakuan kombinasi ( $\mathrm{P} 4)$ yeast yang terkandung hanya setengah dari kandungan pada ragi tape sehingga proses perombakan gula menjadi alkohol saat fementasi kurang optimal. Pada perlakuan alami (P1) perombakan gula menjadi alkohol terjadi karena adanya kontaminasi dari lingkungan sehingga perombakan gula menjadi lambat dan menghasilkan nilai total gula tertinggi. Sisa gula pada bahan menunjukkan adanya gula yang tidak dimanfaatkan oleh yeast dalam pembentukan alkohol.

\section{Alkohol}

Berdasarkan hasil analisis perbedaan jenis ragi menunjukkan bahwa nilai kandungan alkohol cuka yaitu $0 \%$ pada semua perlakuan, hasil ini sesuai dengan SNI cuka yang mengatur adanya kandungan alkohol pada cuka yaitu maksimal $1 \% \mathrm{v} / \mathrm{v}$. Hal ini dikarenakan selama proses fermentasi berlangsung akan terjadi proses perubahan alkohol menjadi asam asetat. Apabila kadar alkohol pada substrat sesuai dengan lingkungan hidup Acetobacter aceti, maka alkohol akan diubah menjadi asam asetat secara optimal. Menurut penelitian Haumasse (2009) penurunan kadar alkohol terjadi karena pada saat fermentasi berlangsung, kandungan alkohol yang telah dioksidasi oleh Acetobacter aceti akan menghasilkan asam asetat dan $\mathrm{H}_{2} \mathrm{O}$.

Pernyataan diatas didukung hasil penelitian yang dilakukan oleh (Adrista et al., 2016) menyatakan bahwa kadar alkohol menurun dari fermentasi hari ke-0 sampai ke4, dan habis pada fermentasi hari ke-6 sampai ke-10. Pada fermentasi hari ke-0 sampai ke-4, alkohol belum dimanfaatkan secara maksimal oleh Acetobacter aceti, sedangkan pada fermentasi hari ke-6 sampai ke-10, alkohol sudah digunakan secara maksimal oleh 
bakteri Acetobacter aceti untuk pembuatan asam asetat, sehingga jumlah alkohol yang ada pada bahan telah habis.

\section{KESIMPULAN DAN SARAN}

\section{Kesimpulan}

Berdasarkan hasil penelitian yang telah dilakukan dapat diambil kesimpulan sebagai berikut:

1. Jenis ragi pada fermentasi kakao berpengaruh nyata terhadap derajat keasaman $(\mathrm{pH})$, total asam, total padatan terlarut (TPT) dan total gula.

2. Perlakuan penambahan ragi tape $1 \%$ menghasilkan karakteristik cuka terbaik dengan nilai sebagai berikut: $\mathrm{pH} 5,05$, total asam $0,88 \%$, total padatan terlarut $3,33 \%$, total gula $0,59 \%$ dan kadar alkohol $0 \%$.

\section{Saran}

Berdasarkan hasil penelitian yang telah dilakukan, untuk menghasilkan cuka kakao dengan karakteristik terbaik disarankan untuk melakukan penambahan ragi tape sebanyak $1 \%$ pada proses fermentasi.

\section{DAFTAR PUSTAKA}

Adrista, G.G., N.M Wartini, dan W. Arnata. 2016. Pengaruh penambatan etanol dan lama fermentasi lanjutan cairan pulpa hasil samping fermentasi biji kakao terhadap karakteristik cuka kakao. Jurnal Rekayasa dan Manajemen Agroindustri 4, 1-11.

Anonimus. 2017. Statistik Kakao Indonesia 2017. Badan Pusat Statistik. .http://ditjenbun.pertanian.go.id/statistik /2017/KAKAO/pdf. Diakses tanggal 28 Maret 2019.

AOAC. 1990. Official methods of analysis of the association of official analytical chemists. Association of Official Analytical Chemists. Washington DC.
Apriyanto, A., D. Fardiaz, N.L. Puspitasari, Sedarnawati dan S. Budiyanto.1989. Analisa Pangan. Bogor.

Aridona, P.M., N.M. Wartini, dan W. Arnata. 2015. Pengaruh lama fermentasi alam cairan pulpa hasil samping fermentasi biji kakao terhadap rendemen dan karakteristik cuka fermentasi. Jurnal Rekayasa dan Manajemen Agroindustri. 3(3):85-92.

Case, C.L. 2004. The Microbiology of Chocolate.http://smccd.net/accounts/cas e/chocolate.html. Diakses tanggal 17 Mei 2018.

Chin, H.H. 2006. Cocoa pulp juice. Malaysia Cocoa 3(1): 8-9.

Gomes, K. A. dan A. A. Gomes. 1995. Prosedur Statistik Untuk Penelitian Pertanian. UI Press, Jakarta. Muchtadi, T. R. 1989. Teknologi proses pengolahan pangan. PAU Pangan dan Gizi. Institut Pertanian Bogor, Bogor.

Haumasse, M. 2009. Pemanfaatan pulpa kakao untuk memproduksi asam asetat dengan menggunakan ragi roti dan aerasi. Skripsi. Institut Pertanian Bogor, Bogor.

James, C. S. 1995. Analysis chemistry of food. Blackie Academic and Professional. Great Britain.

Muchtadi, T. R. 1989. Teknologi proses pengolahan pangan. PAU Pangan dan Gisi. Institut Pertanian Bogor, Bogor.

Putra,G., Harijono, S. Kumalaningsih dan Aulani'am. 2008. Optimasi kondisi depolimerisasi pulp biji kakao olehenzimpoligalakturonase endojinus. Jurnal Teknik Industri 9 (1): 24-34. 
Silfia, Kamsina, Y. H. Diza dan W. Hermianti. 2017. Pengaruh jenis starter untuk meningkatkan efisiesi waktu fermentasi dan analisis proksimat biji kakao. Balai Riset dan Standardisasi Industri Padang, Padang.

Simbolon, K. 2008. Pengaruh persentase ragi tape dan lama fermentasi terhadap mutu tape ubi jalar. Fakultas Pertanian Universitas Sumatera Utara, Medan.

Sintasari, R.A. 2014. Pengaruh penambahan konsentrasi susu krim dan sukrosa terhadap karakteristik minuman probiotik sari beras merah. Jurnal Pangan dan Agroindustri 2(3): 65-75.

Sudarmadji, S., B. Haryono, dan Suhardi. 1984. Prosedur analisa untuk bahan makanan dan pertanian. Liberty, Yogyakarta. 